\title{
La respuesta visual y textual de la Contrarreforma española a la Reforma protestante
}

\author{
María del Carmen Camarillo Gómez
}

\section{Introducción}

En el siglo XVI España era un imperio enorme pero no gozaba de plena salud, pues en su interior se gestaban movimientos separatistas influidos por el luteranismo y en el exterior enfrentaba peligrosos enemigos (el turco, Inglaterra, Francia y los principados protestantes en Alemania). Por ello podemos decir que la Corona española tuvo que enfrentar dos principales problemas, uno fue el riesgo latente de que el protestantismo germinara lo suficiente como para que en sus dominios se diera una fractura política tal, que llegara a la separación, y otro fue la iconoclastia protestante. El cisma representó un gran reto para los reinos católicos y para Roma que dieron como respuesta la celebración del Concilio de Trento, inaugurado por el papa Paulo III el 13 de diciembre de 1545 y que culminó dieciocho años después en 1563. Este encuentro tuvo veinticinco sesiones de las que emanaron diversos acuerdos en materia del pecado original, los sacramentos (matrimonio, la penitencia y la ordenación sacerdotal), la eucaristía, la lista de libros prohibidos, el purgatorio, el celibato y la veneración a los santos y las reliquias; también se suprimieron las indulgencias y se ratificó la supremacía del papa como figura principal de la Iglesia católica unida.

Una vez concluido el Concilio, España generó una infinidad de obras textuales y visuales que conocemos bajo el género de la Contrarreforma, en esta ocasión nuestra intención es hacer un breve recorrido entre ambos discursos. En primer lugar, abordaremos la respuesta iconográfica e iconológica que se generó ante la iconoclastia protestante promovida principalmente por los calvinistas, poniendo énfasis en el papel que desempeñó la Iglesia militante en la construcción del discurso icónico del barroco español y novohispano. En un segundo momento abordaremos el discurso textual que, a mi juicio, se encuentra mayoritariamente en los tratados sobre la razón de Estado en 
los que podemos identificar claramente que el tema central fue alertar a los príncipes cristianos del gran peligro que representaba la existencia de más de una religión en un territorio, reino o imperio, pues a ojos de los llamados tratadistas españoles la aparición del protestantismo era sinónimo de división e inestabilidad política; por lo que nos referiremos fundamentalmente a los argumentos que esgrimieron para consolidar la idea de la fundamentación del Estado desde los preceptos de la religión católica.

\section{La iconografía del barroco español ante la iconoclastia protestante}

Las noventa y cinco tesis de Martín Lutero no hacen referencia explícita a una crítica por el uso de imágenes dentro de las iglesias cristianas. Sólo encontramos en la tesis 79 que: "Es blasfemia aseverar que la cruz con las armas papales llamativamente erecta, equivale a la cruz de Cristo". Aunque considero que esta tesis es un argumento más contra la opulencia y la corrupción del papado que se enriqueció por lucrar con la venta de indulgencias que pretendían borrar el pecado, y en consecuencia, demostraba que una imagen que era utilizada por el papa en diversas liturgias no podía ser considerada la verdadera cruz de Cristo por estar plagada de corrupción y oropel. Pero fue con Juan Calvino que la iconoclastia se hizo mucho más radical, por ejemplo, en el primer libro de su obra Institución de la religión cristiana, publicada en 1536 en Basilea, encontramos que para él representar a Dios con imágenes es una abominación porque su gloria es corrompida al ser reducida a materiales perecederos como la madera, piedra, plata u oro, ${ }^{1} \mathrm{y}$ para justificar su argumento, cita el Antiguo Testamento: "No te harás imagen, ni ninguna semejanza". ${ }^{2}$ Bajo esta óptica, Calvino afirmaba que Dios condena todas las imágenes, sean esculturas o pinturas, que pretendan representarlo porque eso sería convertirlo en ídolo. En esta tónica y apelando a otro libro de carácter normativo de las costumbres que es el Deuteronomio, enfatiza que no debe el pueblo de Israel hacer imagen de Dios ni adorar ídolos, pues eso es para los otros pueblos (Dt., 4: 15-20), pero el argumento se vuelve problemáticamente violento cuando

${ }^{1}$ Juan Calvino, Institución de la religión cristiana. Países Bajos, Fundación Editorial de Literatura Reformada, 1967, p. 50.

${ }^{2}$ El contexto de esta cita es cuando Yavé ha entregado el decálogo a los hombres y presentándose como el único Dios verdadero, prohíbe cualquier tipo de representación: "No te harás estatua ni imagen alguna de lo que hay arriba, en el cielo, abajo en la tierra, y en las aguas debajo de la tierra" (Ex., 20: 4). Resulta evidente que de lo que se trata es de erradicar cualquier otra representación de algún fenómeno natural, astro o animal que pudiera competir con Yavé. 
Dios permite y ordena que se destruyan los templos y los dioses de los otros pueblos. ${ }^{3}$ Algo muy similar a lo que aconteció en el saqueo de Roma de 1527 o los actos cometidos por el propio Enrique VIII, quien en Gales, cerca de Glastonbury, quemó un cristo de madera que gozaba de gran veneración en el pueblo, mandó quitar todas las imágenes de vírgenes y santos, y sustrajo todas las riquezas y tesoros que los templos y conventos guardaban celosamente:

Si fueras presente, y hubieras visto, como yo vi, profanar templos, derribar los altares, robar los sagrarios, maltratar con injurias y afrentas las imágenes y reliquias de los santos, creo cierto que no pudieras tener las lágrimas ni los gemidos y sollozos, viendo que los hombres que se tienen por cristianos hacían cosas tan crueles y bárbaras, que ningún enemigo de Cristo, ni tirano, en ninguna historia se lee haberlas hecho. ${ }^{4}$

Pero volviendo a los argumentos del reformador francés, éste nos dice que siendo Dios incorpóreo no puede bajo ningún punto de vista ser reducido a un espacio corporal determinado, y mucho menos Dios puede ser reducido a materia inanimada, para demostrarlo, de nueva cuenta recurre a los libros de los profetas Isaías, Oseas y Miqueas que demuestran la necesidad imperiosa de destruir a los ídolos. Esta necesidad de destruir cualquier imagen se justificaba porque una imagen no puede representar la verdadera gloria e infinitud de Dios y en consecuencia, aquellos que veían en las imágenes un mecanismo pedagógico mentían porque el conocimiento que se adquiere por medio de los sentidos es falso. Para fortalecer su argumento, Calvino recurre a la autoridad de los padres de la Iglesia, entre ellos a san Agustín, quien aseguraba que las imágenes han disminuido el temor que se debe tener a Dios y han conducido al error, sobre todo, en lo que se refiere al culto a los ídolos y a los demonios. En consecuencia, podemos decir que para Calvino el uso de imágenes y la pretensión de que éstas permiten a los fieles acceder al conocimiento de Dios es un subterfugio que sólo fomenta la ignorancia, la idolatría y la superstición, pues a su juicio, con las imágenes los hombres erróneamente creen que están

3 "Ustedes destruirán totalmente todos los sitios en donde los pueblos que van a desalojar han dado culto a sus dioses. Ustedes lo harán tanto en los altos cerros como en las lomas y bajo los árboles frondosos. Demuelan, pues, sus altares, rompan sus pedestales, quemen sus troncos sagrados y hagan pedazos las esculturas de sus dioses. Procuren borrar, en dichos lugares, hasta el nombre de sus dioses" (Dt., 12: 3). Esto mismo recupera Calvino de san Agustín que en La ciudad de dios en el libro décimo octavo, capítulo XXXI, donde el obispo de Hipona recuerda al profeta Naun que anuncia el mandato divino de destruir estatuas y falsas escrituras.

${ }^{4}$ Pedro de Ribadeneyra, Historia de la Contrarreforma. Madrid, Biblioteca de Autores Cristianos, 1945, p. 1013. 
viendo a Dios como si la divinidad estuviese encerrada entre sus dimensiones sin comprender que como la majestad de Dios no se puede ver con los ojos es ilícito crear imágenes que la representen.

La fiebre iconoclasta de Calvino llegó a tal punto que afirmó erróneamente que las iglesias católicas no tenían ninguna imagen del bautismo, la última cena y otras ceremonias que sí podrían tener un aspecto edificante, y sí, por el contrario, estos templos estaban plagados de imágenes horribles:

En cuanto a las pinturas o estatuas que dedican a los santos, ¿qué otra cosa son sino dechados de una pompa disoluta, e incluso de infamia, con los cuales, si alguno quisiera conformarse, merecería ser castigado? Porque las mujeres de mala vida se componen más honestamente y con más modestia en sus mancebías que las imágenes de la Virgen en los templos de los papistas; ni es mucho más decente el atavío de los mártires. Compongan pues, sus imágenes e ídolos con algo siquiera de honestidad, para que puedan dorar sus mentiras al pretender que son libros de cierta santidad. ${ }^{5}$

Para redondear sus disertaciones, Calvino hace un rastreo histórico acerca de las controversias iconoclastas que se han dado a lo largo de la historia, ${ }^{6}$ donde deja claro que estas supuestas diferenciaciones entre "latría" y "dulía" con las que los adoradores de imágenes pretenden defender su proceder, son en realidad trampas discursivas, pues a su juicio, si latría significa honra o veneración y dulía servicio, entonces los papistas veneran y honran a Dios pero sirven a los santos, lo que para él es absurdo en tanto que la honra y el servicio deben ser ofrecidos solamente a Dios.

Ante la iconoclastia protestante y el discurso calvinista, el Concilio de Trento en su última sesión, celebrada los días 3 y 4 de diciembre de 1563, en el apartado que se refiere a la invocación, veneración y reliquias de los santos y de las sagradas imágenes acordaba que:

Enseñen con esmero los obispos que por medio de las historias de nuestra redención, expresadas en pinturas y otras copias, se instruye y confirma el pueblo recordándole los artículos de la fe, y recapacitándole

${ }^{5}$ J. Calvino, op. cit., p. 55.

${ }^{6}$ Nos recuerda Calvino que el primer momento iconoclasta ocurrió entre 730 y 842 en el Imperio Bizantino con León III, quien ordenó quitar la imagen de Cristo de la puerta principal del palacio de Constantinopla. Mientras que entre el 814 y el 842 se vivió en la región el segundo periodo iconoclasta con el emperador armenio León $\mathrm{V}$, cuya postura se oficializó en el sínodo que se celebró en el 815 en Santa Sofía. Finalmente, Teodora, madre del bisnieto de León V, proclamó la restitución de las imágenes en el 843. 
continuamente en ellos: además que se saca mucho fruto de todas las sagradas imágenes, no sólo porque recuerdan al pueblo los beneficios y dones que Cristo les ha concedido, sino también porque se exponen a los ojos de los fieles los saludables ejemplos de los santos, y los milagros que Dios ha obrado por ellos, con el fin de que den gracias a Dios por ellos, y arreglen su vida y costumbres a los ejemplos de los mismos santos; así como para que se exciten a adorar, y amar a Dios, y practicar la piedad. ${ }^{7}$

Así, tenemos que se pide a los obispos recrear ante los fieles una y otra vez las historias que dan testimonio de fe y obediencia, acción que se podía llevar a cabo a través del uso de imágenes o de relatos (escritos u orales), pues no debemos olvidar que en ambos casos el aprendizaje que se adquiría era continuo, de ahí que la imagen y el relato tenían que ser conservados en lo profundo de la memoria como un recuerdo constante de los dones que Dios ha otorgado a todo su pueblo. Esta titánica labor en buena medida la llevaron a cabo los miembros de la Compañía de Jesús, quienes lograron con la pintura y la arquitectura un lenguaje comprensible para todos. Éste era un discurso que conjugaba armónicamente la razón y la emoción, puesto que se estimulaban los sentidos a la vez que se exigía saber y poder dominarlos para alcanzar la verdadera contemplación. En los jesuitas encontramos, nos dice Alfonso Alfaro, ${ }^{8}$ una ciencia barroca en la que converge, por una parte, un conocimiento racional y, por otra, un conocimiento sensible que se expresa entre la inteligencia y la revelación.

En 1598 el jesuita Louis Richeome publicó en Burdeos una obra titulada Trois discours pour la religion catholique, les saints et les images en donde elabora una brillante argumentación acerca de la licitud de las imágenes religiosas. Marc Fumaroli nos dice que el padre Richeome hace una diferenciación entre ídolo pagano e imagen cristiana, en respuesta clara a las objeciones ya expuestas por Calvino: "El ídolo se presenta como inmediata y materialmente divino. La imagen es una representación mnemotécnica de lo divino. El hombre, 'hecho a la imagen y semejanza de Dios', no es un ídolo de Dios, sino su creación y su representación en el tiempo y en el espacio terrenales". 9

Pero el jesuita va más allá y afirma que Cristo mismo buscó con las imágenes no sólo representar la encarnación divina, sino hacerla presente a través de los tiempos, porque la divinidad que hace visible lo oculto excede la imagen

${ }^{7}$ Obtenido de http://multimedios.org/docs/d000436/p00000.htm\#4-p0.14.1.

${ }^{8}$ Alfonso Alfaro, "El gran teatro del cielo", en Artes de México. México, 2005, núm. 76, p. 77.

9 Marc Fumaroli, "Los jesuitas y la apologética de las imágenes sagradas", en Artes de México. México, 2004, núm. 70, p. 22. 
misma y se muestra cada vez tomando vida, creándose y recreándose. Y para demostrarlo nos recuerda también tres hechos que dejaron como testimonio imágenes de Cristo, el primero de ellos una imagen instantánea de Jesús, que éste mismo envió al rey de Edesa Abgaro, ${ }^{10}$ la segunda imagen es el retrato que se formó en el lienzo conocido como la Verónica cuando una mujer en el vía crucis secó el rostro de Cristo, y la tercer imagen es el famoso sudario de Turín, donde se dice se plasmó el cuerpo martirizado y sangrante de Jesús en su mortaja. En estos tres casos - nos dice el padre Richeome y nos recuerda Fumaroli- podemos ver que Cristo quiso dejar un testimonio de su vida, su agonía y su muerte plasmadas en imágenes para que fuesen recordadas por siempre, y con ellas estuviera presente el mensaje que subyace en cada momento de su vida.

En el ámbito arquitectónico hay muchos ejemplos del poder pedagógico y retórico de la imagen, tal es el caso del Transparente de la catedral de Toledo, obra de Diego de Tomé, que por su extraordinaria belleza e impactante diseño no podemos más que suspender nuestro pensamiento y abandonarnos a su discurso que abraza nuestros sentidos tal como lo promueve este mensaje visual y sensitivo que pretendía generar en el espectador fe y devoción y quizá, en casos extraordinarios, el éxtasis místico a partir de una retórica abrumadora y plural pero unida por un mensaje muy claro. Otro caso paradigmático es el conjunto de retablos que se encuentra en la iglesia de San Francisco Javier en Tepotzotlán, México, o qué decir del inigualable Altar de los Reyes, en la catedral metropolitana de México, obra de Gerónimo de Balbás entre 1718 y 1725. Mención especial debemos hacer de las imágenes alegóricas que representaban el triunfo de la Iglesia y el triunfo de la religión, pues estaban plagadas de elementos iconográficos que hacen referencia al triunfo del bien sobre el mal y la supremacía del papa. Todos ellos respuesta clara y contundente a la Reforma protestante y de paso a la lucha contra el turco y demás enemigos.

De la imagen de Jesús encontramos infinidad de representaciones, en el caso específico de la Nueva España tenemos por ejemplo que la teatralidad devocional llegó a tal punto que se fabricaron Cristos articulados, esto es, que eran figuras móviles que tenían aplicaciones de caucho policromado para representar las heridas de Cristo y todos los momentos de la Pasión ${ }^{11}$ y generar así en los fieles mayor devoción. Por otra parte, tenemos que las obras pictóricas y escultóricas del barroco católico estaban sustentadas en la literatura

${ }^{10} \mathrm{El}$ rey Abgaro, quien como sabemos, según cuenta la leyenda, estaba muy enfermo y pidió a Jesús que le ayudara a curarse, Cristo no lo visitó pero le dijo que una vez que ascendiera a los cielos le enviaría a un emisario con su poder, el poder estaba concentrado en una imagen milagrosa de su rostro.

${ }^{11}$ Vid. Pablo Amador, "Testigos de un pasado devoto. El acervo escultórico", en vv. AA., 80 años, 80 obras. El Museo del Carmen. México, INAH/Conaculta, 2010, p. 32. 
hagiográfica que se refiere a los santos, estos relatos expresaban una forma de vida ejemplar que se entretejía con la realidad y la fantasía. Por ejemplo, en el Flos sanctorum de Ribadeneyra, publicado en Madrid en 1599, podemos encontrar que en la vida de los santos el martirio es un elemento constante que nos muestra el dolor, el sufrimiento y la muerte física como testimonios de que estos sacrificios los acercaban más a la vida eterna y a su encuentro con Dios. Sirviendo de ejemplo, sobre todo, a las grandes mayorías de hombres y mujeres que vivían alejados de la fe, el discurso visual retomó todos estos atributos; así podemos ver miles de ejemplos, entre los que tenemos las imágenes de santa Úrsula, santa Teresa, san Aproniano, san Andrés, san Hermenegildo, santa Catalina de Alejandría o san Lorenzo.

No quisiéramos concluir este apartado sin antes hacer referencia al tema de las reliquias, las que cumplían también la misión de ser un vehículo discursivo que, a través de los sentidos, buscaba dar testimonio de la grandeza de Dios. En el siglo IV las reliquias eran un medio para la consagración de los templos, por lo que se creó la imperiosa necesidad de buscar y trasladar reliquias para ese fin, lo que incluso llegó a convertirse en un tráfico ilegal, puesto que la demanda era mucha y las reliquias eran pocas y difíciles de obtener. Esto es algo que utilizó Calvino para argumentar en contra del uso de éstas, en su obra titulada Tratado de las reliquias, ${ }^{12}$ publicada en 1543 en Ginebra, evidenciaba la falta de certeza en la autenticidad de éstas, ya que una misma reliquia podía ser exhibida en varios templos a la vez, incluso llega a ridiculizar esta práctica denunciando que se llegaron a adquirir reliquias tales como "el santo prepucio" o "vestigios de los pañales o la cuna de Jesús", ${ }^{13}$ eso sin olvidar que hubo un sin número de templos que adquirieron tantas astillas de la verdadera cruz que si fueran unidas todas harían una cruz enorme. Por todo lo anterior, podemos decir que en resumidas cuentas, para Calvino, el uso de reliquias no es más buscar a Cristo en el lugar equivocado, aferrándose a las cosas materiales en vez de escuchar su palabra.

\section{La buena razón de Estado ante el cisma protestante}

En 1513 Maquiavelo publicaba El príncipe y con esto, se supone, nacía la idea de razón de Estado, que no es más que la máxima del obrar político, el motor

${ }^{12}$ El título completo de la obra es: Aviso muy útil y de gran provecho del invento que la cristiandad ha hecho de todos los cuerpos de los santos y de las reliquias que están tanto en Italia como en Francia, Alemania, España y otros países y reinos.

${ }^{13}$ José Luis Bouza, Religiosidad contrarreformista y cultura simbólica del barroco. Madrid, Consejo Superior de Investigaciones Científicas, 1990, p. 30. 
del Estado y su propia ley, ${ }^{14}$ que tiene como fin garantizar la estabilidad y la salud del mismo. En primera instancia debemos apuntar que la virtud (que sería un antecedente de la idea de la razón de Estado) propuesta por Maquiavelo era de carácter político, no moral y mucho menos religioso, de tal suerte que era válido el uso de la simulación y la disimulación ${ }^{15}$ si con ello se preservaba o incrementaban los dominios del Estado. Pero quizá el aspecto que encendió los focos rojos, desde la perspectiva de los tratadistas españoles, fue el que la religión era concebida como un medio de la política, pues no debemos olvidar que para el secretario florentino es vital que el príncipe ponga especial atención en la religión, sus preceptos y sus augurios, ya que del manejo que de éstos haga dependerá que su reino, o república, permanezca sano y unido, sin importar si el príncipe lo considera una verdad o es una devoción auténtica, en tanto que sólo se requiere que sea prudente, cuidadoso y poseer un gran conocimiento para obtener los beneficios necesarios.

Así tenemos que, ante las afirmaciones de Maquiavelo, los españoles reaccionaron enérgicamente desarrollando ampliamente el tema de la razón de Estado. Por lo que respecta al uso que la razón de Estado hace de la religión como mecanismo de control y factor unificante el padre Ribadeneyra nos dice, en la dedicatoria que hace al cristiano y piadoso lector de su Tratado de la religión y las virtudes que debe tener el príncipe cristiano, que Maquiavelo se equivoca al afirmar que Dios no guía a los príncipes sino su propio valor y consejo. A su decir el error radica en que ni Maquiavelo ni sus seguidores los políticos creen que haya una verdadera ni una falsa religión porque no creen en ninguna y sí sólo la utilizan conforme a las necesidades o requerimientos de sus propios intereses expresados bajo la máscara de la razón de Estado. Estos postulados se volvieron más peligrosos cuando algunos Estados europeos adoptaron el protestantismo como religión, pues a juicio de Ribadeneyra hicieron uso de una falsa religión para crear unidad en sus reinos y en consecuencia se volvieron enemigos de la verdadera religión.

Así pues, surge discursivamente la buena razón de Estado que es la que ha de conducir a los príncipes por el camino recto y justo basado en las virtudes, mismas que han de ser guiadas por la prudencia. Virtud que ha de impedir que el príncipe actúe con disimulación y engaño que puedan poner en peligro la sanidad y conservación del Estado mismo, por ello las recomendaciones que nuestro autor hace al príncipe cristiano han de ser: "[...] mirar por la fe de sus súbditos, y defender la religión católica, y amparar la Iglesia, que no se haga censor de la fe ni juez de la religión, ni superior de las causas y ministros

${ }^{14}$ Tal como lo afirma Friedrich Meinecke, La idea de la razón de Estado en la edad moderna. Madrid, Centro de Estudios Constitucionales, 1997, p. 4.

${ }^{15}$ Nicolás Maquiavelo, El príncipe. México, Alianza, 1992, pp. 62, 84, 98 y 111. 
de la Iglesia, pues no lo es, sino hijo de ella y defensor, y como tal debe oír, defender y amparar". ${ }^{16}$

Ribadeneyra recuerda los pasajes de las Sagradas Escrituras que hacen referencia a la manera en cómo los reyes y líderes del pueblo de Israel escucharon y siguieron los designios de Dios para el buen gobierno de su pueblo. La razón natural muestra el camino que han de seguir los reyes para que entiendan que en su papel de reyes están obligados a amar y temer a Dios, porque no obedecer o no temer a Dios no sólo causa mal al rey sino a toda la república. El argumento se fortalece cuando Ribadeneyra afirma que no amar ni temer a Dios es el más grave error que puede cometer el rey, pues como capitán que tiene a su cargo una nave cualquier error le puede conducir al naufragio, tragedia que sólo puede evitarse si los príncipes siguieren siempre la ley de Dios: "Aquí está cifrado todo lo que se puede decir a este propósito: que tengan la ley de Dios delante de sus ojos; que ella sea su espejo, su dechado, su vida y su luz; con ella se aconsejen, con ella se acuesten, con ella se levanten, con ella coman, con ella trabajen y descansen, con ella hagan paz y guerra, den vida y muerte al que la mereciere". ${ }^{17}$

Así las cosas, con la fuerza, la sabiduría y el poder que al príncipe le otorga la religión es que puede gobernar bien y enfrentar a sus enemigos, pues el único requerimiento que necesita es la fe, la constancia y la obediencia. Obediencia que no sólo debe darse con el príncipe sino con todos los súbditos, pues ésta era garantía de orden y estabilidad para el Estado; de ahí que para los tratadistas españoles no podía existir la posibilidad, bajo ninguna circunstancia, que dentro del reino existiera lo que podríamos llamar libertad de conciencia o de culto.

Consecuencia lógica es que se afirme que con Ribadeneyra la razón de Estado se vuelve una razón de interés y de religión, creando así un vínculo indisoluble que pretendía encontrar el fundamento universal de un imperio cristiano, pues como nos dice Jorge Velázquez, ${ }^{18}$ la tarea era establecer una unidad absoluta del género humano por medio de la religión y su triunfo, lo que en realidad representó la intención de mundanizar el poder pero sin secularizarlo.

Este poder fuerte y unificado en torno a la religión demuestra su oposición a Maquiavelo, ya que para Ribadeneyra a la religión le corresponde hacer un Estado y no al Estado hacer una religión, y mucho menos era tarea de un

${ }^{16}$ Pedro de Ribadeneyra, Vidas de santos. Antología del Flos sanctorum. Madrid, Lengua de Trapo, 2000, pp. 17-18.

${ }^{17}$ P. de Ribadeneyra, "Tratado de la religión y virtudes", en Obras escogidas. Madrid, Atlas, 1952, p. 467.

${ }^{18}$ Jorge Velázquez, Antimaquiavelismo y razón de Estado. Ensayos de filosofía política del barroco. México, Ediciones del Lirio, 2011, pp. 19 y 51. 
príncipe determinar qué religión se debía practicar en su Estado, porque lo político no puede nunca definir o determinar a la religión dependiendo de sus gustos o intereses particulares. Las consecuencias de esta actitud voluble y cambiante en el príncipe podían acarrear en su Estado todo un ambiente de inestabilidad y de permisibilidad, pues si el príncipe cambiaba de religión luego entonces esto también estaría permitido para los súbditos, borrándose así toda posibilidad de orden y de obediencia. En ese sentido, el príncipe bajo ninguna circunstancia debía permitir dentro de su reino que los vasallos profesasen distinta religión, ya que esto, además de ser un pecado, representaba un grave peligro a la estabilidad y el orden en su reino, ya que para Ribadeneyra era imposible que un hereje y un católico pudieran establecer relaciones de convivencia, y por el contrario, crearían sublevaciones y violencia:

[Mostraré] que no debe el príncipe cristiano permitir herejes y hombres de varias y contrarias sectas en sus Estados, si quiere cumplir bien con el oficio y obligación de católico príncipe; y que es imposible que hagan buena liga el católico y el hereje en una misma república, y que no sucedan por esta mezcla grandes alteraciones y revueltas, que son la ruina y destrucción de los reinos y Estados... el oficio más principal del rey es mirar por la religión católica y conservarla en su pureza. ${ }^{19}$

Caso especial es la representación que la literatura emblemática ha hecho de esta buena razón de Estado y su fundamento, que varios autores han denominado como razón de religión. Para poder ilustrarlo sólo tomaremos algunos ejemplos de la extraordinaria obra de Diego Saavedra Fajardo, La idea de un príncipe político cristiano representada en cien empresas, obra que se inscribe dentro de la literatura emblemática, cuya principal característica es transmitir un mensaje moralizante por medio de la palabra y la imagen. Todos los tratadistas españoles consideraban que el legítimo ejercicio del poder proviene, en primera instancia, de la voluntad de Dios, quien hace posible la existencia y la movilidad de todas las cosas, incluidos los reinos. Bajo esta premisa, para Saavedra Fajardo el gobierno del príncipe no debía alejarse de los designios de Dios ni de las virtudes cristianas, pues atreverse a hacerlo le representaría un gobierno corrupto y débil condenado a la ruina y al desprestigio. Para grabarlo en la memoria del príncipe, Saavedra recurre a una impactante imagen en la empresa 18 (véase imagen 1$)^{20}$ donde podemos ver sobre la imagen del mundo un cetro coronado por una media luna y un

${ }^{19}$ José Fernández Santamaría, Razón de Estado en el pensamiento español del barroco (1595-1640). Madrid, Centro de Estudios Constitucionales, 1986, p. 59.

${ }^{20}$ Con la leyenda: "A Deo" (De Dios). 


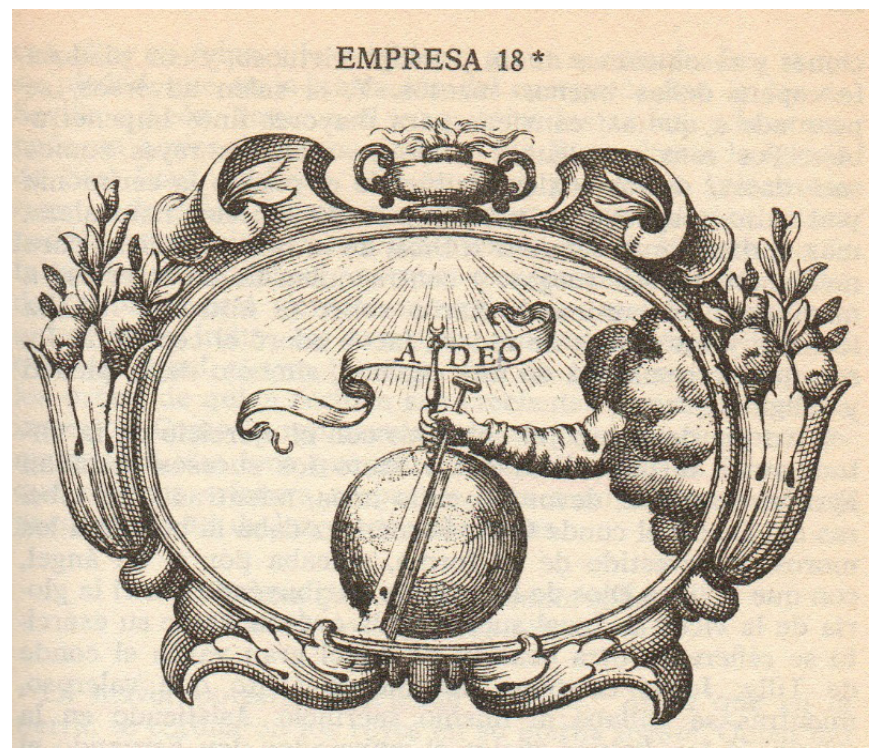

Imagen 1

timón (elementos que representan el poder terrenal de los príncipes), pero sobre ellos se encuentra el cetro divino iluminado por los rayos del sol cuya luz ordena y clarifica las acciones y decisiones del príncipe cristiano para evitarle cometer vicios o disimular virtudes.

Un aspecto medular en la Contrarreforma y motivo de muchas controversias fue el papel de la religión en la política, para Saavedra la justicia y las leyes en las repúblicas debían estar sustentadas en la religión, debido a que su jurisdicción no sólo comprendía el seguimiento de los actos externos o públicos, también juzgaba los actos internos o privados. Esta capacidad que tenía la religión de dirigir los deseos y las voluntades de los súbditos de inmediato fue advertida por algunos políticos que pensaron en la religión como un invento de la política, ${ }^{21}$ lo que para Saavedra representó un acto impío, puesto que para él, como para Ribadeneyra, la religión era base de la política y no al revés. Su argumento lo podemos observar en la empresa 24 (véase imagen 2 ) $^{22}$ que tiene como grabado, en primer plano, una brújula apuntando a la estrellas, suponemos que la brújula se encuentra en un navío porque al fondo podemos ver el mar. En este caso la brújula representa a la religión que siempre condu-

${ }^{21}$ Muy probablemente aquí Saavedra está pensando en Maquiavelo, quien consideró que la religión era un medio eficaz para el control político y una pieza clave en la razón de Estado.

${ }^{22}$ Con la leyenda: "Immobilis ad immobile nvmen" (Fiel a la voluntad inmóvil). 


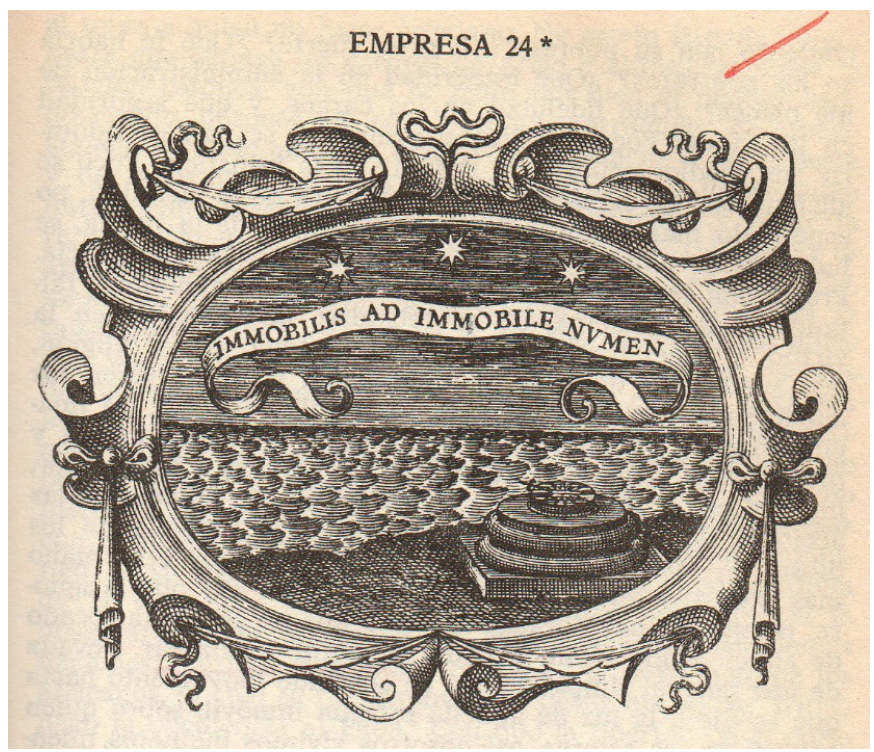

Imagen 2

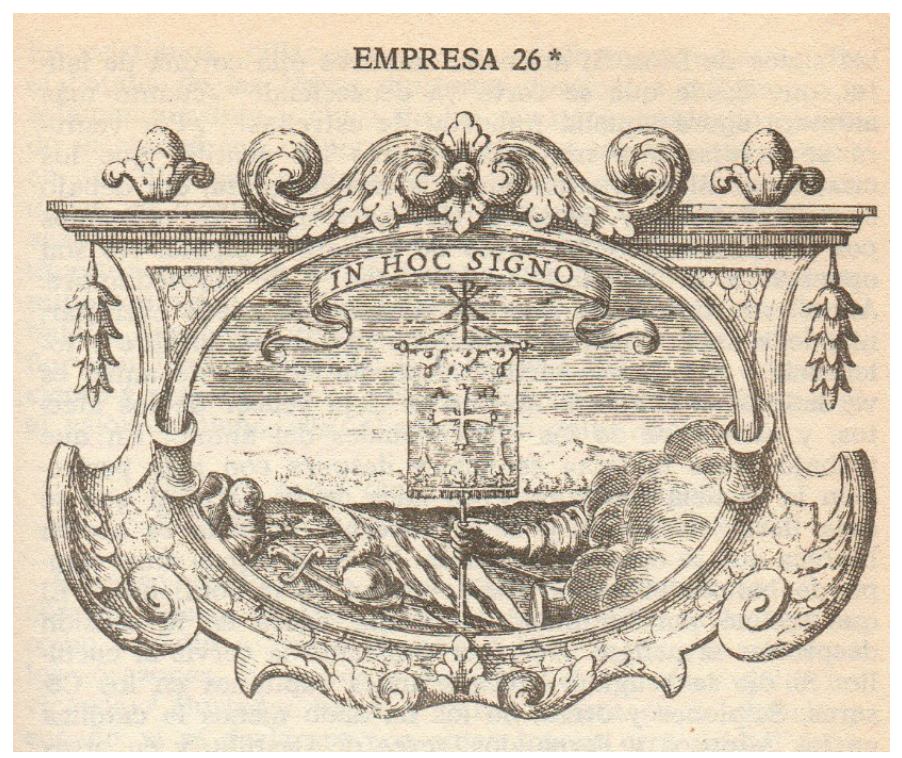

Imagen 3 
ce por el camino correcto. Esta guía en todo momento debía ser seguida por el príncipe, quien estaba obligado a evitar distraerse en falsas miras (malos consejos o falsas creencias) que le conducirían a la ruina. Aquí encontramos una figura recurrente que nos habla del papel mnemotécnico de la literatura emblemática, para simbolizar el Estado con frecuencia se dibujaba un barco en alta mar que era conducido por el príncipe, quien a lo largo de su travesía se iba a encontrar con múltiples contratiempos que debía saber sortear con destreza, habilidad, disciplina, virtud y evidentemente con la ayuda de los preceptos cristianos para poder llegar a buen puerto. ${ }^{23}$

En clara alusión a Maquiavelo, ${ }^{24}$ Saavedra inicia su reflexión en torno a la empresa 26 (véase imagen 3), ${ }^{25}$ afirmando que es una opinión impía el asegurar que los gentiles poseen más fortaleza y valor que los cristianos debido a que el cristianismo hace a los hombres débiles, y para demostrarlo nos dice que la humildad y la mansedumbre no son oponentes de la fortaleza, por el contrario, son virtudes indispensables para tener fortaleza y valor para alcanzar la victoria, tal como sucedió en la batalla de Lepanto. ${ }^{26}$ En la empresa 36 Saavedra recurre a la imagen que se utilizó en el estandarte del emperador Constantino ${ }^{27}$ para ejemplificar cómo Dios ayuda y acompaña a los cristianos en las batallas, tal como vemos en esta empresa que recrea el estandarte con una cruz franqueada por las letras alfa y omega (que simbolizan el principio y el fin de todas las cosas) y coronado por las letras X y P que hace referencia

${ }^{23}$ La metáfora del barco la encontramos en varias ocasiones dentro de las empresas saavedrinas, la número 36 titulada: "In contaria dvcet", nos habla de las dificultades que debe sortear el príncipe (capitán) a la vez que nos muestra que de la adversidad el príncipe debe sacar aprendizaje, lo mismo nos dice el autor en la empresa 37 con el mote: "Minimvm eligendvm", donde afirma que mientras la prudencia da prevención para evitar contratiempos, la fortaleza otorga la tolerancia de soportarlos con dignidad una vez que se han presentado. De igual manera vemos la influencia que tuvo en Saavedra la obra de Alciato, quien en varios emblemas representó a las naves. Por ejemplo, en el emblema número 72 encontramos un barco que sufre las inclemencias de la tormenta por haberse apartado de la virtud; o en la empresa 42 nos muestra que a pesar de la tormenta la nave salió a flote y llegó a tierra firme gracias a la ayuda del delfín, que como el príncipe debe conducir a su reino a terreno seguro.

${ }^{24}$ N. Maquiavelo, Discursos sobre la primera década de Tito Livio. Madrid, Alianza, 2008, pp. 198-199.

${ }^{25}$ Con el mote: "In hoc signo" (Con esta señal).

${ }^{26}$ La batalla de Lepanto fue un combate naval que ocurrió el 7 de octubre de 1571 en el golfo de Lepanto, Grecia, donde se enfrentaron los turcos otomanos y la coalición cristiana conocida como la Liga Santa conformada por España, los Estados pontificios, la Orden de Malta, la República de Génova, el Ducado de Savoya y la República de Venecia, resultando triunfadores los cristianos.

${ }^{27}$ Que según cuenta la leyenda fue una señal que se apareció en el cielo para anunciarle su victoria en contra de Magencio. 


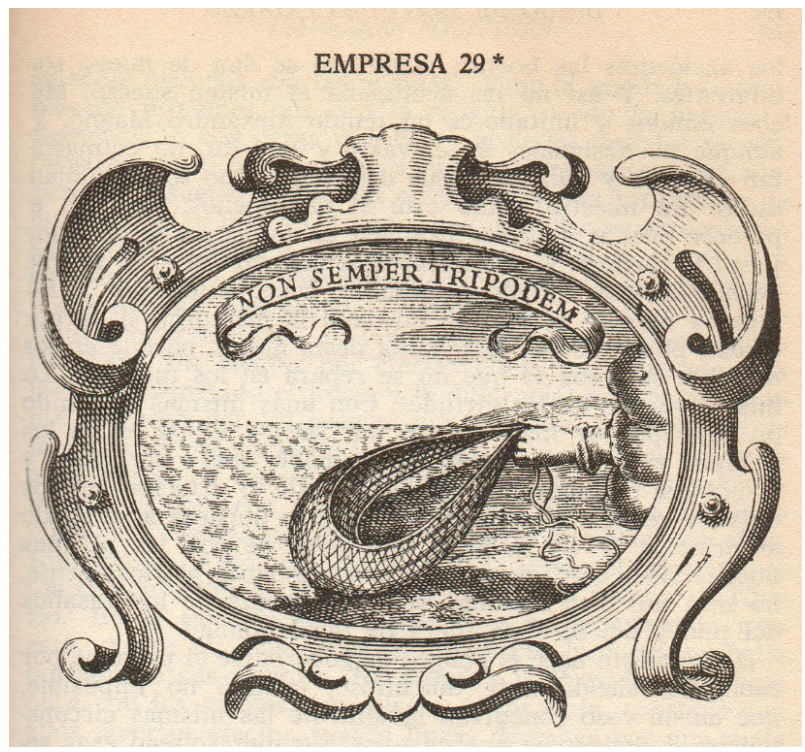

Imagen 4

al nombre de Cristo. El estandarte se yergue victorioso sobre una escena de guerra con lo que se afirma que la religión siempre saldrá triunfante en la batalla contra el enemigo y el mal.

Por otra parte, tenemos que dentro del pensamiento político del barroco español la providencia juega un papel central y la obra saavedriana no es excepción, en varias empresas encontramos referencias al tema, pero sin ánimo de extendernos demasiado sólo comentaremos dos de ellas. Por ejemplo, en la empresa 29 (véase imagen 4$)^{28}$ el autor nos relata una vieja historia sobre unos pescadores que un día en lugar de recoger peces con su red obtuvieron del mar un trípode de oro. Este relato fue ampliamente difundido en la comunidad y muy pronto otros pescadores quisieron tener la misma suerte, lamentablemente para ellos lo intentaron mil veces sin éxito. La moraleja de esta historia es que no se debe emular un hecho que es o parece bueno, sin tomar en consideración los factores que influyeron para que eso pasara. Por ello el príncipe debe tomar con mucho cuidado los ejemplos de la historia, ver sus causas y las consecuencias de su implementación, porque:

De todo esto nace el peligro de gobernarse el príncipe por ejemplos, siendo muy dificultoso, cuando no imposible, que en un caso concu-

${ }^{28}$ Con el mote: "Non semper tripodem" (No siempre trípode). 


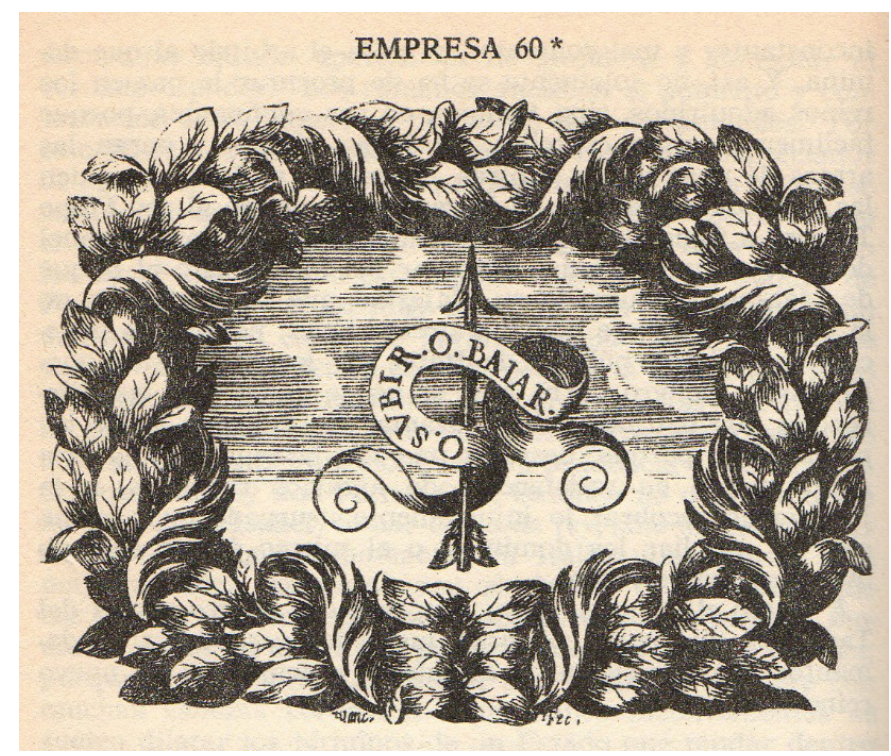

Imagen 5

rran igualmente las mismas circunstancias y accidentes que en otro [...] Solamente aquellos ejemplos se pueden imitar con seguridad que resultaron de causas y razones intrínsecamente buenas y comunes al derecho natural y de las gentes, porque éstas en todos tiempos son las mismas; como seguir los ejemplos de príncipes que con religión, o con la justicia o clemencia, o con otras virtudes y acciones morales se conservaron. ${ }^{29}$

Para reforzar esta idea recordamos la empresa 60 (véase imagen 5 ) $^{30}$ en la que podemos ver una saeta que no sabemos si está subiendo o bajando, lo que debe recordarle al príncipe que las cosas terrenas no son eternas y son muchas las causas que intervienen para que las monarquías y repúblicas crezcan o desaparezcan; sin embargo, el común denominador en todas ellas nos remite a que son causas provocadas por la imprudencia humana. Siguiendo la idea escolástica de la primera causa (Dios), que no siempre actúa de forma directa sobre las causas segundas, abre la posibilidad a cierta libertad en los hombres (o libre albedrío) para actuar de manera correcta o incorrecta. Sin embargo, lo anterior no sugiere que el poder de decisión del ser humano se

${ }_{29}$ Diego Saavedra Fajardo, Idea de un príncipe cristiano representada en cien empresas, pp. 192-193.

30 Titulada: "O subir o bajar". 


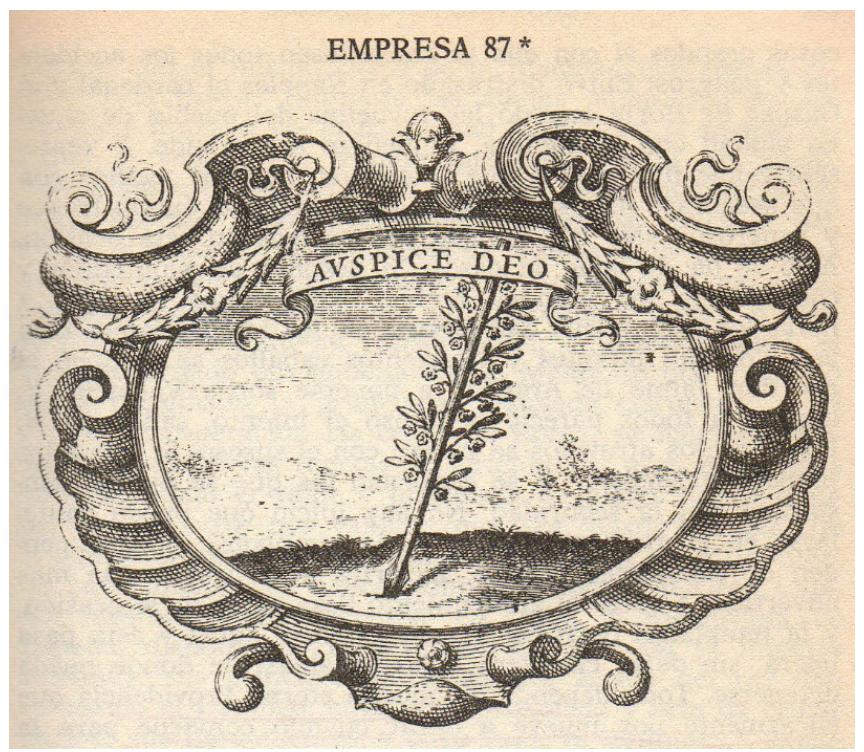

Imagen 6

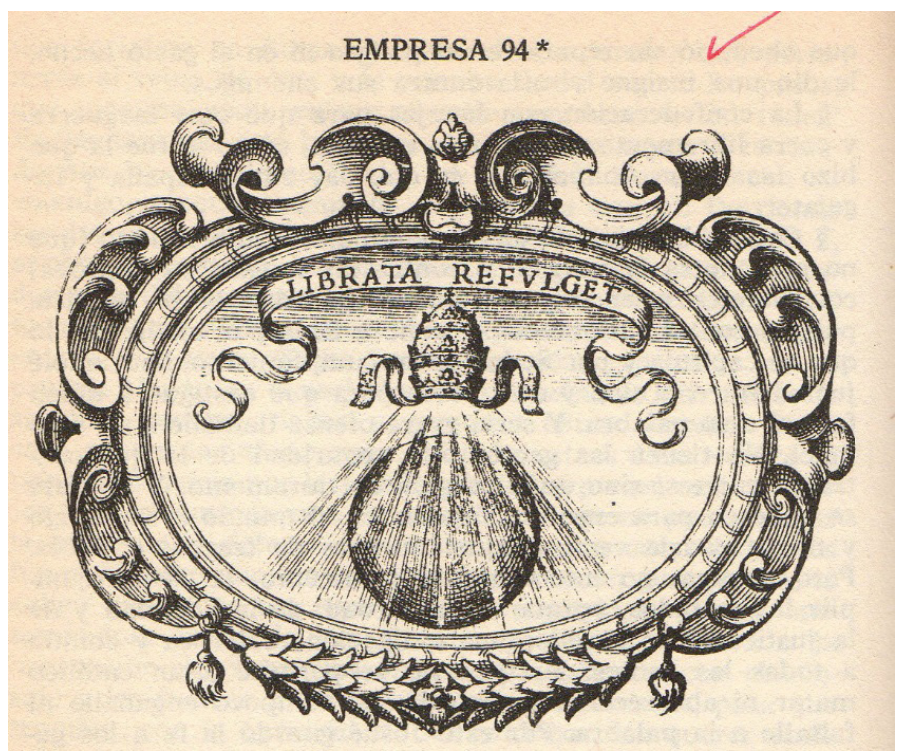

Imagen 7 
sobreponga a la providencia, por el contrario, aun dentro de las posibilidades en las que actúa la libertad humana está siempre presente el designio divino.

Por su parte en la empresa 87 (véase imagen 6) titulada "Avspice Deo" (Auspicio de Dios), Saavedra Fajardo nos muestra que los auspicios de Dios están por encima de la prudencia o la temeridad humana, pues todo depende, en última instancia, de la providencia que se impondrá siempre a las acciones humanas, para ilustrarlo vemos una especie de palo puntiagudo utilizado para la labranza, que a pesar de no haber penetrado la tierra, ésta ha florecido por gracia de Dios, de igual manera cualquier acción que emprenda un príncipe para tener éxito deberá contar con la protección divina para garantizar su éxito: "y así, no es el valor o la prudencia la que levanta o sustenta (aunque suele ser instrumento) las monarquías sino aquel impulso superior que mueve muchas causas juntas, o para su aumento o para su conservación; y entonces obra el caso, gobernado por aquella eternamente, lo que antes no había imaginado la prudencia". 31

Así con una fuerte e inquebrantable alianza entre la política y la religión tenemos que en la empresa 96 (véase imagen 7 ) $^{32}$ titulada Librata refvlget se observa una tiara que corona al mundo y que, a su vez, con sus rayos divinos ilumina a la tierra de manera equitativa, cual sol en equinoccio, ${ }^{33}$ y es que el sol representa la justicia, pues a todos ofrece su luz y calor. Esta tiara es como una piedra en donde las coronas terrenales se reconocen y a la que desean emular en virtud, bondad y justicia. Así, por el contrario, todas aquellas coronas impías que se rehúsan a seguir el ejemplo de la tiara están hechas de plomo y de estaño, y por ello el tiempo las corroe y deteriora sin llegar a consolidarse más de cinco generaciones.

Para finalizar, recordamos que en la empresa 95 (véase imagen 8) titulada Nevtri Adhaerendvm ${ }^{34}$ podemos observar dos mares contenidos por un istmo, lo que en términos políticos podemos traducir que ante dos potencias, una cristiana y otra turca, se debe mantener un equilibrio sustentado por la Sede apostólica y la religión católica, y que en última instancia es Dios con su providencia quien establece este equilibrio, mismo que puede expresarse uniendo reinos o bien separándolos, tal como fueron sus designios con Francia y España. Ahora bien, es importante señalar que este equilibrio providencial del que hablamos no implica asumir una actitud neutral, es más, la neutralidad es peligrosa y nociva para el príncipe que la pone en práctica, pues le acarrea enemigos por ambos bandos:

${ }^{31}$ D. Saavedra Fajardo, op. cit., p. 92.

${ }^{32}$ Que significa: Resplandeciente equilibrio.

${ }^{33}$ Aquí muy probablemente tendremos que incluir la importancia de las metáforas que en la época se hacían en torno a los cuerpos celestes.

${ }^{34}$ Estar dentro de lo neutral. 


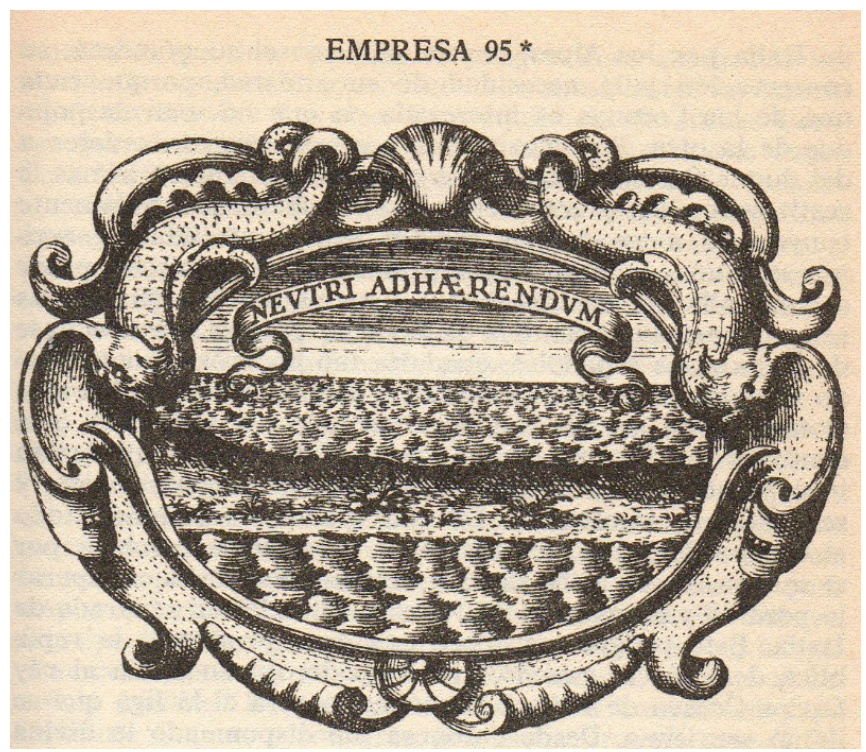

Imagen 8

La neutralidad siempre es dañosa al mismo que la hace; y así lo dijo el rey don Alonso de Nápoles por los seneses (habiéndose perdido, pensando salvarse, con la neutralidad), que les había sucedido lo que a dos que habitan a medias una casa, que el de abajo da humo al de arriba, y el de arriba moja al de abajo. Grandes daños causó a los tebanos el haberse querido mantener neutrales cuando Jerjes acometió a Grecia. ${ }^{35}$

Es interesante el argumento que nuestro autor expone para afirmar que es a España a quien hay que apoyar en lugar de Francia dentro de la disyuntiva de que ambos reinos se definen como cristianos, y es que dice que no se trata de apoyar a España para que adquiera más poder sino el objetivo es evitar que Francia crezca y avance, lo que además crea, a su juicio, condiciones de paz.

\section{Conclusiones}

Con el desarrollo del protestantismo en Europa, y particularmente con el calvinismo, la lucha en contra de Roma se enfocó a un nuevo objetivo: las imágenes religiosas que utilizaban las iglesias católicas. Como pudimos ver la

${ }^{35}$ D. Saavedra Fajardo, op. cit., p. 157. 
lucha iconoclasta sostenía que Dios es irrepresentable y que las imágenes de los santos con todo y sus reliquias son idolatría; enardecidos con este discurso, la lucha fue más allá de las ideas y se tornó en episodios violentos cuando los protestantes irrumpieron en las iglesias católicas destruyendo las imágenes y saqueando sus tesoros. Ante este panorama, el pensamiento contrarreformista español dio respuesta elaborando sublimes y conmovedoras imágenes y creando majestuosas catedrales e iglesias con retablos desbordantes de un discurso dedicado a los sentidos y a la fe. Teniendo siempre como guía y horizonte a la religión católica, los tratados sobre la buena razón de Estado buscaron subsanar la fractura que representó el cisma protestante y su subsecuente expansión, agrupando razones, esfuerzos y voluntades en torno al vínculo irrompible del Estado y la religión católica, que a ojos de estos pensadores garantizaría la unidad y fortaleza que el Estado necesita para subsistir, para ello construyó un discurso político que pretendió apuntalar su imperio a partir de la virtud y del principio conservativo. Hoy no nos queda más que desentrañar todo este discurso icónico y textual que en muchas ocasiones ha quedado reducido al olvido o bien ha sido condenado al descrédito por ser considerado ejemplo de atraso y oscurantismo irracional y premoderno. 